\title{
Program Paket Masa Depan BPTN Syariah Perspektif Fiqh Muamalah
}

\author{
Fathul Khair \\ Institut Agama Islam Negeri Sultan Amai Gorontalo \\ fatu1209@gmail.com
}

\begin{abstract}
Until 2018, BTPN Syariah's profits have reached Rp. 7.27 trillion and making BTPN Syariah one of the largest Islamic commercial banks (BUS) in Indonesia. This is due to BTPN Syariah's main product, Paket Masa Depan (PMD) program. However, in the implementation of the PMD program in Depok's mobile marketing Syariah (MMS) Sleman district, some parties do't understand the contents of the PMD contract so they think PMD financing was the same as loans that benefit from interest. This research is a field research. This research aims to describe and analyze BTPN Syariah PMD program in MMS Depok muamalah figh perspective. Data collection in this study was obtained from interviews, observations, and documentation. The results of this study are the implementation of PMD in MMS Depok not in accordance with company regulations and figh muamalah. PMD implementation mistakes at MMS Depok namely; does not submit a murabahah contract, so that carrying out financing raises the perspective of interest loans; the customer deviates from the use of funds that are't in accordance with the agreement; the object of the contract in financing is money, not goods; predetermined financial ceiling; and customers cannot withdraw their wadiah savings at any time but by ordering and can only be compile by routine meeting sentra.
\end{abstract}

Key words: PMD, murabahah bil wakalah, wadiah

\begin{abstract}
Abstrak
Hingga tahun 2018, omset BTPN Syariah telah mencapai Rp. 7,27 triliun dan menjadikan BTPN Syariah sebagai salah satu bank umum syariah (BUS) terbesar di Indonesia. Hal tersebut disebabkan karena produk utama BTPN Syariah yaitu program Paket Masa Depan (PMD). Akan tetapi, pada pelaksanaan program PMD di mobile marketing syariah (MMS) Depok kabupaten Sleman, beberapa pihak tidak paham isi akad PMD sehingga beranggapan pembiayaan PMD sama seperti kredit yang mengambil untung dari bunga. Penelitian ini adalah penelitian lapangan. Penelitian ini memeliki tujuan untuk mendeskripsikan dan menganalisis program PMD BTPN Syariah di MMS Depok persfektif fiqh muamalah. Data dalam penelitian ini diperoleh dari wawancara, observasi, dan dokumentasi. Hasil dari penelitian ini adalah pelaksanaan PMD di MMS Depok tidak berjalan sesuai ketentuan prosedur perusahaan dan fiqh muamalah. Kekeliruan pelaksanaan PMD di MMS Depok yaitu; tidak menyebutkan akad murabahah, sehingga pelaksanaan pembiayaan menimbulkan prespektif pinjaman berbunga; nasabah melakukan penyimpangan penggunaan dana pembiayaan yang tidak sesuai dengan akad atau perjanjian; objek akad dalam pembiayaan merupakan bentuk uang, bukan barang; plafond pembiayaan telah
\end{abstract}


ditentukan sebelumnya; dan wadiah yang tidak bisa diambil kapan saja, tetapi melalui pemesanan dan hanya boleh dilakukan ketika pertemuan rutin sentra.

Kata kunci : PMD, murabahah bil wakalah, wadiah

\section{PENDAHULUAN}

Salah satu sarana yang mempunyai peranan strategis dalam kegiatan perekonomian adalah perbankan. peran strategis tersebut disebabkan dari fungsi utama perbankan sebagai financial intermediary, yaitu sebagai wahana yang dapat menghimpun dan menyalurkan dana masyarakat secara efektif dan effesien (Muh Sabir, 2012:79-86). Dalam Undang-undang No.10 Tahun 1998 pasal 1 ayat 2, menjelaskan pengertian bank, yaitu badan usaha yang menghimpun dana dari masyarakat dalam bentuk simpanan dan menyalurkannya kepada masyarakat dalam bentuk kredit dan atau bentuk-bentuk lainnya, dalam rangka meningkatkan taraf hidup rakyat banyak. Pengertian tersebut menjelaskan bahwa bank merupakan perusahan atau industri jasa yang berfungsi untuk menghimpun dana dan menyalurkan dana. Dalam siklus tersebut, bank berperan sebagai pihak yang menjembatani antara pemilik modal atau pihak yang memiliki kelebihan dana dengan pihak yang membutuhkan dana.

Sistem perbankan yang dilaksanakan di Indonesia, diatur dalam Undang-undang No.10 Tahun 1998 tentang perbankan. Undang-undang tersebut menjelaskan perbankan di Indonesia terdiri dari dua kategori, yaitu bank umum dan bank perkreditan rakyat. Kedua jenis bank tersebut melaksanakan kegiatan dengan sistem konvensional atau syariah. Hal ini mendeskripsikan bahwa Indonesia menganut sistem perbankan ganda, yaitu ketika bank konvensional dan bank syariah beroperasi secara berdampingan. Kemudian bank syariah di Indonesia mulai tumbuh pesat dalam bentuk Bank Umum syariah atau full fledged Islamic bank, unit usaha syariah atau bank konvensional yang membuka cabang syariah, dan office channeling atau gerai syariah di kantor bank konvensional.

Undang-undang No.10 tahun 1998 memberikan penjelasan bahwa bank syariah memiliki peluang yang besar untuk tumbuh dan berkembang di Indonesia. Dalam undang-undang tersebut disebutkan bahwa bank umum diberikan kesempatan untuk menjalankan dual banking sistem, yaitu pelaksanaan sistem konvensional dan syariah secara bersamaan. Bank syariah merupakan bank yang menjalankan fungsi intermediasinya berdasarkan prinsip-prinsip syariat islam. Fungsi dan peran bank syariah, diantaranya sebagai wadah menghimpun dana dari masyarakat atau usaha dalam bentuk tabungan (mudharabah dan wadiah), deposito (mudharabah), dan giro (wadiah), serta menyalurkan dana kepada sektor riil yang membutuhkan sesuai dengan prinsip syariah. Sehingga, menjadikan bank syariah sebagai wadah investasi bagi dunia usaha (baik 
dana modal maupun dan rekening investasi) dengan menggunakan alatalat investasi yang sesuai dengan prinsip syariah. Seperti murabahah/pembiayaan dengan akad jual beli), mudharabah/pembiayaan dengan akad bagi hasil, ijarah/sewa menyewa, dan musyarakah/pembiayaan dengan akad penyertaan modal (Huda dan Heykal, 2013:26).

Keberadaan lembaga keuangan dalam Islam adalah vital karena kegiatan bisnis dan roda ekonomi tidak akan berjalan tanpanya. Bank Syariah adalah bank yang beroperasi dengan tidak mengandalkan pada bunga (Mustapha, 2012:41). Bank syariah dapat diartikan sebagai lembaga keuangan atau perbankan yang operasional dan produknya dikembangkan berlandaskan dan berpedoman pada al-quran dan hadis nabi saw. Antonio membagi menjadi dua pengertian, yaitu bank yang beroperasi dengan dengan prinsip syariah islam dan bank islam. Bank yang beroperasi sesuai dengan prinsip syariah islam adalah bank yang dalam operasionalnya berpacu pada ketentuan-ketentuan syariah islam, khususnya yang berkaitan dengan tata cara bermuamalat secara islam. Bank islam adalah bank yang beroperasi dengan prinsip syariah islam dan bank yang tata cara beroperasinya mengacu kepada ketentuan-ketentuan al-quran dan hadis (Syafi'i Antonio, 2001:18-19).

Sistem Perbankan syariah sebenarnya tidak terbatas pada nasabah yang beragama islam saja, layanan dan produk-produk perbankan syariah dapat dinikmati oleh siapa saja dan tidak tergantung agama yang dianut nasabah, selama nasabah bersedia mengikuti cara berbisnis yang dibolehkan secara syariah. Masyarakat membutuhkan lembaga keuangan yang kuat, transparan, adil, dan berkomitmen membantu masyarakat meningkatkan perekonomiaan (Maulidiana, 2011:71-79).

Produk-produk perbankan syariah sangat bervariatif dibanding produk-produk bank konvensional. Salah satu produk perbankan syariah yang sering digunakan dalam bentuk pembiayaan adalah murabahah. Pembiayaan murabahah dalam lembaga keuangan syariah hampir mencapai $80 \%$ - 95\% dari setiap pembiayaan. Hal tersebut juga terlihat pada produk yang ditawarkan pada Faysal Islamic Bank, Bahrain Islamic Bank, Kuwait Finance House, Bank Islam Malaysia, dan lainnya. Hal ini menunjukkan bahwa pembiayaan murabahah menjadi pembiayaan primadona pada perbankan syariah (Hadi, 2011:193-208).

Hingga juni 2018, terdapat 13 Bank Umum Syariah (BUS) di Indonesia. Salah satu BUS yang terbaru adalah Bank Tabungan Pensiunan Nasional (BTPN) Syariah, yang memisahkan diri dari bank induk Bank Tabungan Pensiunan Nasional (BTPN) pada juni 2014. Hingga akhir tahun 2018, BTPN Syariah terhitung sebagai salah satu BUS yang tercatat memiliki margin mencapai Rp. 7,27 triliyun, menjadikan BTPN Syariah sebagai salah satu BUS terbesar di Indonesia. 
Awalnya, BTPN melakukan akuisis saham perseroan PT. Bank Sahabat Purba Danarta, selanjutnya merubah nama menjadi BTPN Syariah dan memisahkan diri (spin off) pada tahun 2014 menjadi BUS. Sejak saat itu, produk andalan BTPN Syariah adalah produk Paket Masa Depan (PMD). Produk ini diadobsi dari PT. Bank Sahabat Purba Danarta.

Produk PMD merupakan program terpadu BTPN Syariah yang diberikan kepada sekelompok wanita di pedesaan atau perkampungan yang ingin berusaha dan memiliki impian untuk merubah hidup, tapi tidak mempunyai akses ke layanan perbankan. Program PMD ini bertujuan untuk mensejahterakan dan memperdayakan perempuan dengan memberikan akses dan fasilitas-fasilitas perbankan. Kemudian, BTPN Syariah memberikan pelatihan-pelatihan untuk perempuan yang berusaha dan memiliki impian untuk merubah hidup (BTPN Syariah, 2019).

Namun, pelaksanaan program PMD di Kecamatan Depok, Kabupaten Sleman, tidak berjalan sesuai dengan ketentuan standar operasional kantor dan melanggar aturan syariah. Banyak nasabah bank BTPN Syariah di Kecamatan Depok mengeluhkan sistem pelaksanaan PMD karena beranggapan pelaksanaan PMD memakai sistem bunga, bukan margin.

Dari masalah di atas, peneliti merasa perlu untuk melakukan studi lebih lanjut dan melakukan penelitian mengenai penerapan produk PMD BTPN Syariah MMS Depok persfektif fiqh muamalah. Penelitian ini bertujuan untuk mendeskripsikan dan menganalisis penerapan program PMD BTPN Syariah MMS Depok menurut persfektif fiqh muamalah.

\section{METODE PENELITIAN}

Penelitian ini merupakan penelitian deskriptif. Penelitian deskriptif adalah penelitian yang berusaha memberikan gambaran secara sistematis dan cermat fakta-fakta aktual dan sifat-sifat populasi tertentu (Zuriah, 2009:14).

Ditinjau dari pemakaiannya, penelitian ini adalah penelitian lapangan (field reaserch) dengan menggunakan pendekatan metode kualitatif. Metode kualitatif terdiri dari pengamatan, observasi, wawancara, dan penelaahan dokumen. Penggunaan metode ini dikarenakan metode kualitatif yang paling tepat digunakan dan sesuai dengan kebutuhan dalam penenelitian ini (J. Moleong, 2010:9).

Informan dalam penelitian ini terdiri dari pihak Manager sentra (MS) MMS Depok, Senior Community Officer (SCO) MMS Depok, Community Officer (CO)/pembina sentra (PS) MMS Depok, Quality Assurance (QA) BTPN Syariah area Jawa Tengah dan DI Yogyakarta, dan nasabah BTPN Syariah di MMS Depok yang masih aktif dalam pembiayaan, paham, dan menguasai masalah yang berkaitan dengan penelitian, serta terlibat langsung dengan masalah penelitian. 


\section{Fiqh Muamalah}

Secara etimologi, fiqh berasal dari kata الفقه yang mempunyai arti pemahaman atau pengertian. Sedangkan menurut terminologi, fiqh pada awalnya merupakan pengetahuan tentang keagamaan yang meliputi seluruh ajaran agama, baik berupa ibadah, aqidah, maupun akhlak. Namun, pada perkembangannya, fiqh dimaknai sebagai bagian dari syariah islamiyah, yaitu ilmu pengetahuan tentang hukum syariah islamiyah yang berkaitan dengan perbuatan manusia yang telah dewasa dan berakal sehat yang diambil dari dalil-dalil yang terinci (Munawwir, 1997:1068).

Menurut objek hukumnya, fiqh terbagi menjadi dua kategori, yaitu: hukum-hukum yang berkaitan dengan ibadah, seperti; thaharah, shalat, puasa, zakat, haji, nazar, dan segala sesuatu dalam bentuk ibadah yang berkaitan langsung antara manusia dengan Tuhannya; hukum-hukum muamalah, yaitu hukum-hukum yang berkaitan dengan hubungan antar sesama manusia, atau hubungan manusia dengan lingkungan sekitarnya, baik yang bersifat kepentingan pribadi maupun kepentingan seperti hukum-hukum sewa menyewa, perjanjian dagang, dan lain-lain.

Secara bahasa, kata muamalah berasal dari kata amala-yu'amilu yang maknanya saling bertindak, saling mengamalkan, dan saling berbuat. Sedangkan, menurut istilah muamalah merupakan tukar menukar barang atau sesuatu yang memberi manfaat dengan cara yang ditentukan. Muamalah dapat dimaknai sebagai aturan agama yang mengatur hubungan antar sesame manusia dan hubungan antar manusia dengan alam sekitarnya tanpa memandang perbedaan (Syafei, 2001:14).

Aturan-aturan agama yang mengatur hubungan antar sesama manusia, dapat kita jumpai dalam hukum islam, seperti perwalian, warisan, perkawinan, hibah perdagangan, wasiat, perkoperasian, perburuan, dan lain-lain. Aturan-aturan agama yang mengatur hubungan antara manusia dengan lingkungannya bisa kita jumpai dalam hukum islam, seperti tentang mata pencarian, makanan, minuman, dan cara memperoleh rizki dengan cara yang dihalalkan maupun yang diharamkan.

Landasan fiqh muamalah terdapat dalam surat An Nahl ayat 89 yang artinya: "(Dan ingatlah) akad hari (ketika) Kami, bangkitkan pada tiap-tiap umat seorang saksi atas mereka dari mereka sendiri, dan Kami datangkan kamu (Muhammad) menjadi saksi atas seluruh umat manusia. Dan Kami turunkan kepadamu al kitab (Al Qur'an) untuk menjelaskan segala sesuatu dan petunjuk serta rahmat dan kabar gembira bagi orang-orang yang berserah diri."

Ruang lingkup fiqh muamalah yang diangkat dalam penelitian ini ada tiga, yaitu akad, murabahah bil wakalah, dan wadiah. 


\section{Akad}

Menurut bahasa, akad (al-aqdu) jamaknya (al-uqud) mempunyai dua pengertian, yakni secara hissi dan ini merupakan makna asli akad yang berarti menguatkan atau mengikat (Hidayat, 2015:1). Isitilah akad terdapat dalam UU No. 21 tahun 2008 tentang bank syariah dinyatakan dalam pasal 1 angka 13; akad merupakan kesepakatan tertulis antara pihak bank syariah atau UUS dan pihak lain yang memuat adanya kewajiban dan hak untuk masing-masing pihak sesuai dengan prinsip syariah. Akad menurut Ahmad Azhar Basyri ialah suatu perikatan antara ijab dan qabul dengan cara yang dibenarkan syara' yang menetapkan akibat-akibat hukum. Ijab adalah pernyataan pihak pertama mengenai isi perikatan yang diinginkan dan qabul adalah pernyataan pihak kedua untuk menerimanya.

Ditinjau dari hukum islam, perjanjian yang sering disebut sebagai akad merupakan suatu perbuatan yang secara sengaja dilakukan dan dibuat oleh dua pihak atau lebih, berdasarkan persetujuan masing-masing pihak. Dengan kata lain, akad adalah perikatan antara ijab dan qabul secara yang dibenarkan oleh syarak, yang menetapkan persetujuan kedua belah pihak (Hasbi, 1997:28). Akad meliputi tiga hal, yaitu: perjanjian, persetujuan dua belah pihak atau lebih, dan perikatan. Akad dalam muamalah memiliki tingkatan yang sangat penting bagi keabsahan transaksi yang terjadi diantara para pihak yang membuat akad atau berakad. Berakhirnya akad dapat disebabkan karena kematian, fasakh, atau karena adanya pihak lain dalam akad mauquf (Suhendi, 2008:46).

Akad merupakan rukun yang sangat penting guna memastikan terjadinya transaksi, sehingga substansi perjanjian/kontrak/akad dalam setiap transaksi menjadi semakin nyata dan menentukan sah atau tidaknya transaksi syariah. Hal tersebut dikarenakan: akad merupakan prosesi puncak pada setiap transaksi syariah; akad/perikatan/perjanjian dalam transaksi syariah berbeda dengan kontrak/akad dalam transaksi non syariah, dimana dalam akad syariah lebih mengedepankan kerelaan/keridhoan pihak-pihak yang terkait dengan akad, sedangkan akad non syariah menetapkan persentase tingkat bunga tertentu kepada nasabah dalam keadaan terpaksa; dan akad transaksi syariah telah disepakati bersama (Arifin, 2014:165-183).

\section{Murabahah bil Wakalah}

Secara etimologi, murabahah berasal dari kata ribh (الرّبْْح) yang mempunyai makna pertambahan atau kelebihan dalam perdagangan. Dengan kata lain, ribh bisa dimaknai sebagai laba, keuntungan, margin, atau faedah (Munawwir, 1997:463). Secara sederhana, murabahah merupakan jual beli barang pada harga awal kemudian ditambahi keuntungan yang disepakati antara pihak bank dan pihak nasabah. Pada akad murabahah, penjual atau pihak bank menyebutkan harga pembelian 
barang kepada pembeli atau pihak nasabah, kemudian bank mensyaratkan atas keuntungan dalam jumlah tertentu. Pada perjanjian murabahah, pihak bank membiayai pembelian barang yang dibutuhkan nasabah dengan membelikan barang itu dari pemasok. Selanjutnya menjual barang tersebut kepada nasabah dengan harga barang yang ditambahkan dengan margin (Sudarsono, 2004:62).

Prosedur dan persyaratan dalam penyaluran dana dalam pembiayaan akad murabahah di bank Syariah, tidak hanya dilakukan berdasarkan ketentuan Hukum Islam, tapi juga berdasarkan ketentuan hukum perbankan syariah, serta ketentuan khusus yang diterapkan di bank Syariah, yaitu negosiasi pembiayaan murabahah antara calon nasabah dengan bank syariah, kemudian dilanjutkan dengan pemenuhan kelengkapan dokumen yang diperlukan yang meliputi: dokumen pribadi, legalitas usaha, dan dokumen pendukung usaha, yang kesemuanya telah ditentukan secara khusus dalam Standar Operasional Prosedur (SOP) bank syariah (Sri Rejeki, 2013:19-31).

Murabahah yang dipraktikkan dalam perbankan syariah adalah murabahah li al-amir bi al-syira, yaitu transaksi jual beli, dimana nasabah mengajukan permohonan kepada pihak bank syariah untuk membelikan barang yang dibutuhkan dan nasabah tersebut berjanji akan membeli barang tersebut dari bank syariah secara murabahah, yaitu sesuai harga pokok pembelian ditambah dengan margin atau keuntungan serta biayabiaya lain yang disepakati, kemudian nasabah akan melakukan pembayaran secara cicilan berkala kepada bank syariah pada waktu yang telah disepakati. Dalam hal ini, pihak bank wajib memberitahu secara jujur kepada nasabah harga pokok barang, besarnya margin, dan biaya-biaya lain yang diperlukan (Lathif, 2012:69-78).

Pada perkembangan bank syariah di Indonesia, akad murabahah dilakukan dalam tiga kategori. Pertama, murabahah yang konsisten terhadap fiqh muamalah. Pada prakteknya, bank syariah atau lembanga keuangan syariah akan membeli barang yang diinginkan nasabah, setelah barang dibeli bank, selanjutnya dijual kepada nasabah dengan harga awal ditambah margin atau keuntungan. Kedua, murabahah yang mirip dengan kategori pertama, perbedaan terletak pada perpindahan kepemilikan barang, perpindahan kepimilikan barang langsung dari penjual kepada nasabah, kemudian pembayaran barang tersebut dilakukan antara bank dan penjual. Kategori terakhir, bank dan nasabah melakukan perjanjian murabahah yang diawali dengan akad wakalah, nasabah akan mewakilkan bank untuk membeli sendiri barang yang diinginkan, bank hanya akan menerima bukti pembelian seperti kwitansi atau nota. Kategori kedua dan ketiga adalah murabahah yang paling sering digunakan oleh perbankan syariah di Indonesia (Lathif, 2012:69-78). 
Wakalah secara bahasa artinya menyerahkan sesuatu. Dalam istilah syara' yaitu seseorang yang menyerahkan sesuatu urusan kepada orang lain, pada apa yang boleh diwakilkan menurut syara', agar orang yang mewakilkan itu dapat melakukan sesuatu yang diserahkan kepadanya selagi yang menyerahkan itu masih hidup. Perwakilan sah dilakukan dalam permasalahan kawin, jual beli, talak, menggadai, memberi, dan sesuatu barang yang memiliki hubungan dengan muamalah. Dalam hal ini, wakalah memiliki makna memberikan kuasa kepada orang lain untuk menyelesaikan urusan kepada orang lain (Idris, 1969:67).

Dalam konsep fiqh, wakalah merupakan suatu pendelegasian wewenang yang dibolehkan menurut syara' selama unsur dalam wakalah terpenuhi. Sehingga, rukun-rukun dan syarat-syarat wakalah harus sesuai dengan Syariah, karena wakalah secara terminologis adalah mewakilkan yang dilakukan oleh orang yang punya hak tasharruf kepada orang yang juga memiliki hak tasharruf tentang suatu yang boleh diwakilkan (Afrida, 2016:155-166).

Murabahah bil wakalah adalah jual beli murabahah yang diawali akad wakalah. Dalam akad ini, pihak penjual mewakilkan pembelian barang kepada nasabah, dengan demikian akad pertama yang dilaksanakan adalah akad wakalah, setelah akad wakalah selesai yang ditandai dengan penyerahan barang dari nasabah ke lembaga keuangan syariah selanjutnya dilakukan akad murabahah. Pada ketentuan fatwa DSN No: 04/DSNMUI/IV/2000 pasal 1 ayat 9: jika bank hendak mewakilkan kepada nasabah untuk membeli barang dari pihak ketiga, akad jual beli murabahah harus dilakukan setelah barang, secara prinsip, menjadi milik bank. Sesuai dengan ketentuan fatwa DSN MUI di atas, akad murabahah bil wakalah bisa dilakukan dengan syarat barang yang dibelikan nasabah sepenuhnya sudah milik lembaga keuangan syariah, setelah barang tersebut dimiliki lembaga keuangan syariah maka akad murabahah dapat dilaksanakan (DSN MUI, 2006:26).

Dalam hukum perbankan syariah, pelaksanaan akad harus memenuhi rukun dan syarat. Ascarya dalam bukunya akad dan produk bank syariah, tentang murabahah melalui wakalah atau mewakilkan, pelaksanaan murabahah bil wakalah dapat digambarkan sebagai berikut: 


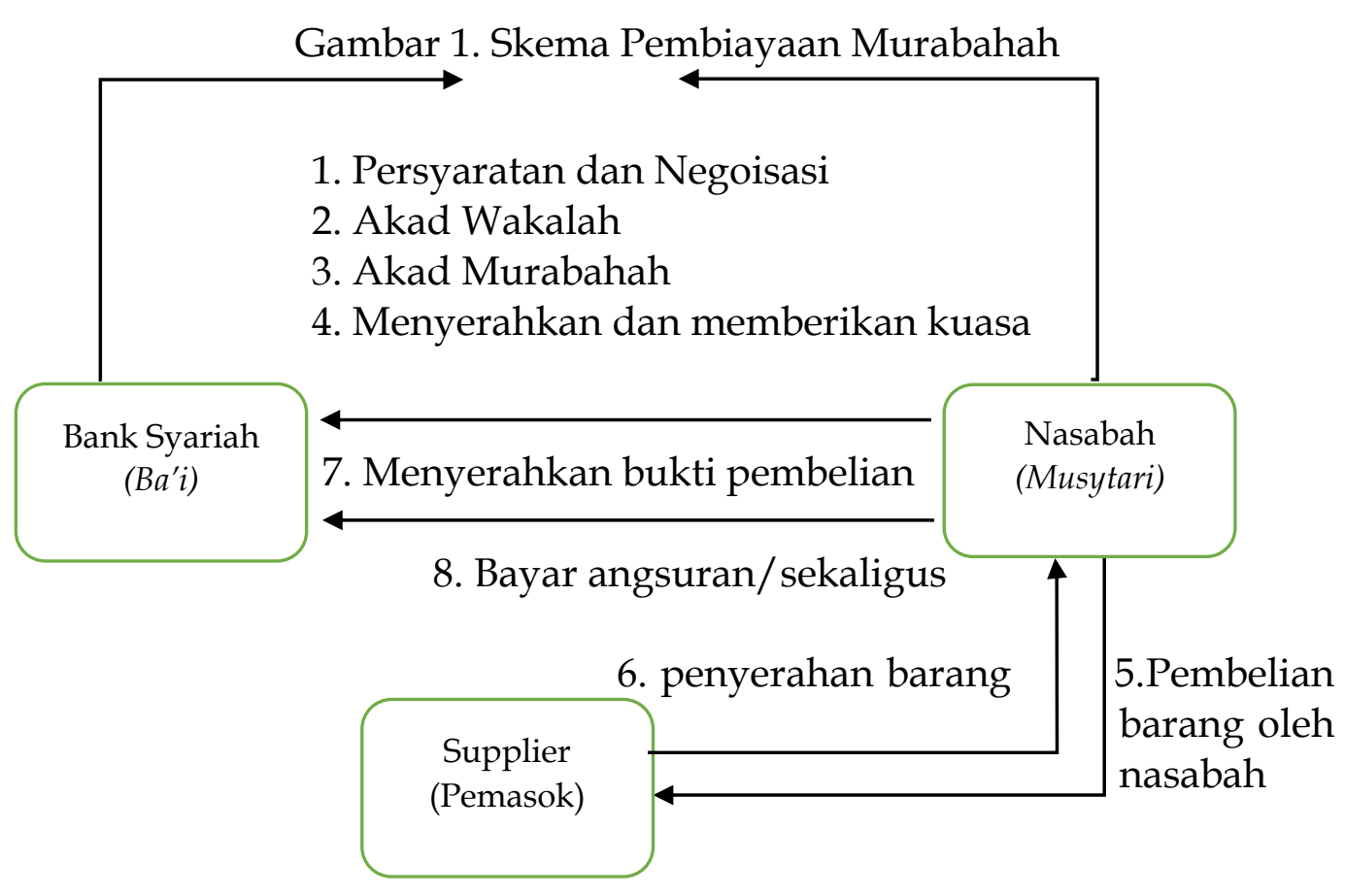

Sumber: Ascarya (2013)

\section{Wadiah}

Barang titipan dalam fiqh dikenal dengan sebutan wadiah, menurut Bahasa, wadiah ialah sesuatu yang ditempatkan bukan pada pemiliknya supaya dijaga (ma wudi'a 'inda ghair malikihi layahfadzuhu), yang berarti wadiah adalah memberikan, makna yang kedua dari segi bahasa adalah menerima, seperti seseorang berkata: awda 'tubu, yang artinya aku menerima harta tersebut darinya (qabiltu minhu dzalika al-mal liyakuna wadi'ah ' indi), sehingga secara Bahasa wadiah memiliki dua makna, yaitu memberikan harta untuk dijaga dan pada penerimaannya (Ahmad Basri, 2011:255-264).

Kata wadiah berasal dari wada'asy syai'a, yaitu meninggalkan sesuatu. Sesuatu yang seseorang tinggalkan pada orang lain supaya dijaga, karena dia meninggalkannya pada orang yang sanggup menjaga. Secara harfiah, wadiah dapat diartikan sebagai titipan murni dari satu pihak ke pihak lain, baik individu maupun badan hukum yang harus dijaga dan dikembalikan kapan saja si penitip menghendakinya. Wadiah merupakan akad satu pihak kepada pihak lain dengan menitipkan suatu barang untuk dijaga secara layak menurut kebiasaan.

Wadiah adalah penitipan, yaitu akad seseorang kepada yang lain dengan menitipkan benda untuk dijaganya secara layak. Apabila ada kerusakan pada benda titipan tidak wajib menggantinya, tapi bila kerusakan itu disebabkan oleh kelalaiannya maka diwajibkan menggantinya (Ali dan Mokhtar, 2012:6665-6668). 


\section{Prosedur Pembiayaan PMD}

Pemberian program PMD kepada nasabah dimulai dengan menyeleksi calon nasabah yang dilakukan dengan cara sebagai berikut:

1. Pre marketing. Pada tahap ini, pihak MMS melakukan tiga tingkat pertemuan awal, yaitu; silaturahmi dengan aparat (SDA) setempat, pihak MMS mengadakan pertemuan bersama aparat desa, baik itu desa, kelurahan, maupun kecamatan, untuk bersilaturahmi sekaligus mensosialisasikan program PMD yang nantinya diberikan kepada warga di sekitar desa tersebut; Mini meeting (MM), pihak MMS mengadakan kunjungan langsung kepada perempuan-perempuan yang akan dijadikan target market; dan Projection Meeting (PM), adalah tindak lanjut dari MM kepada calon nasabah, untuk menggali kebutuhan calon nasabah, menjelaskan secara detail manfaat, tujuan, dan ketentuan mengenai PMD.

2. Survey dan Wawancara (SW). Survey dilakukan untuk mengetahui lokasi usaha nasabah serta menganalisa omset usaha nasabah agar tim MMS bisa mempertimbangkan jumlah maksimal plafon pembiayaan yang akan diberikan untuk tahap awal. Selanjutnya melakukan wawacara langsung kepada nasabah serta mencari informasi karakter nasabah kepada tetangganya.

3. Memberikan pelatihan dasar keanggotaan (PDK). PDK meliputi pengenalan perusahaan, pengenalan produk, pelatihan-pelatihan, pembentukan grup, pembentukan sentra, penentuan hari pertemuan sentra, dan penentuan lokasi pertemuan sentra. PDK wajib diikuti oleh semua calon nasabah dengan kehadiran 100\%. Pelatihan ini diberikan oleh bank kepada nasabah secara gratis. Calon nasabah wajib lulus PDK sebagai salah satu syarat untuk dapat mengajukan pembiayaan. PDK dilakukan selama lima hari berturut-turut dengan materi yang berbeda-beda bagi nasabah yang baru bergabung dengan pembiayaan PMD. Bagi nasabah yang sudah mendapatkan pembiayaan PMD pada tahap awal dan kemudian ingin melanjutkan ke tahap selanjutnya maka nasabah tersebut mendapatkan PDK selama satu hari atau paling lama tiga hari.

4. Pertemuan rutin sentra (PRS). PRS dilakukan satu kali dalam dua minggu setelah pencairan pembiayaan PMD. Semua kegiatan harus dilakukan pada saat PRS seperti membayar angsuran, setor atau tarik tabungan dan lain-lainnya. PRS dilakukan di tempat yang telah disepakati bersama. 
5. Monitoring usaha (MU) dan surprise visi (SV). MU dilakukan untuk melihat apakah ada perubahan pada nasabah yang telah mendapatkan pembiayaan PMD. MU dilakukan selambatlambatnya satu bulan setelah pencairan. Jika dalam MU didapati nasabah menggunakan pembiayaan tidak sesuai dengan tujuan awal maka pihak bank akan memberikan peringatan dan nasabah terancam tidak bisa mendapatkan pembiayaan lanjutan. SV yang dilakukan secara sampling minimal empat orang nasabah dan dilaksanakan maksimal tiga bulan sejak pembiayaan dicairkan (BTPN Syariah, 2012:80).

\section{Pelaksanaan Program Paket Masa Depan (PMD) di Mobile Marketing Syariah (MMS) Depok}

MMS Depok memiliki delapan orang anggota yang terdiri dari satu orang sebagai bussines center (BC), satu orang sebagai manager sentra (MS), satu orang sebagai senior community officer (SCO), dan lima orang sebagai community officer (CO) atau pembina sentra (PS).

Number of costumer (NoC) atau jumlah nasabah BTPN Syariah di MMS Depok pada tanggal 27 November 2018, berjumlah 1.169 nasabah yang terbagi dalam 153 sentra, dengan estimasi tujuh hingga delapan orang per sentra.

Produk PMD BTPN Syariah memberikan program pembiayaan yang digabungkan dengan program pemberdayaan. Program PMD BTPN Syariah memberikan kesempatan kepada kelompok-kelompok perempuan untuk mendapatkan akses, produk, layanan perbankan serta program pemberdayaan perempuan. Fasilitas program PMD BTPN Syariah meliputi 4 hal, yaitu pembiayaan tanpa jaminan, tabungan tanpa bunga, asuransi atau santunan, dan pelatihan.

Mobile Marketing Syariah (MMS) merupakan pihak bank BTPN Syariah yang berperan memberikan akses kepada masyarakat dan nasabah mengenai produk-produk perbankan, sehingga MMS merupakan pihak yang menghubungkan BTPN Syariah dengan nasabah. MMS sangat berperan penting terhadap pelaksanaan produk perbankan, termasuk dalam pelaksanaan PMD yang menjadi program unggulan BTPN Syariah. Umumnya, MMS melaksanakan kegiatan perbankan dengan cakupan satu kecamatan.

Hasil penelitian di lapangan menunjukkan bahwa MMS Depok tidak menjalankan prosedur pelaksanaan PMD sesuai dengan ketentuan. Banyak prosedur yang diabaikan BTPN Syariah dalam pelaksanaan PMD di MMS Depok.

Pertama, MMS Depok tidak melaksanakan pre marketing. pre marketing terdiri dari silaturahmi dengan aparat setempat, mini meeting, dan projecting meeting. MMS Depok berfokus pada sentra-sentra yang 
telah ada. MMS Depok hanya mengembangkan sentra-sentra yang sudah ada, mengarahkan anggota-anggota sentra mencari teman-teman untuk diajak bergabung di kelompok pembiayaan. Sehingga, pelaksanaan marketing pada MMS Depok melakukan sistem word of mouth atau yang dikenal dengan mulut ke mulut.

Strategi ini cukup berhasil, karena perkembangan dari sentra-sentra setiap bulan semakin meningkat. Jumlah nasabah baru (NoA) pada bulan desember 2018 di MMS Depok mencapati 24 orang dan nasabah yang melanjutkan pembiayaan selanjutnya mencapai 32 orang. Akan tetapi, pelaksanaan marketing MMS Depok tidak menambah jumlah sentra, MMS Depok hanya menambah jumlah nasabah di sentra-sentra yang sudah ada.

Kedua, MMS Depok sering melakukan manipulasi data pada form survey dan wawancara agar meloloskan nasabah mendapatkan pencairan. Manipulasi dilakukan untuk melewati batas minimal pendapatan bersih dari calon nasabah. Hal ini dilaukan MMS Depok untuk mencapai target bulanan yang dituntut dari perusahaan. Sehingga pelaksanaan survey dan wawancara tidak sepenuhnya berasal dari data nasabah. Bahkan, pada form aplikasi permohonan pembiayaan \& pembukaan rekening (AP3R) kolom pembelian barang, barang yang akan dibeli untuk pembiayaan dimanipulasi sebagai formalitas. Nasabah nantinya akan menggunakan pembiayaan dengan membelanjakan hal lain di luar perjanjian.

Ketiga, MMS Depok jarang melakukan pelatihan dasar keanggotaan (PDK). PDK berisikan pelatihan-pelatihan kepada calon-calon nasabah. PDK bertujuan untuk memberikan informasi tentang BTPN Syariah, produk pembiayaan yang akan diberikan (syarat dan ketentuan), pembentukan kelompok atau sentra (menentukan ketua kelompok, tempat pertemuan, dan waktu pertemuan), dan pelantikan nasabah. PDK dilakukan selama lima hari bagi nasabah baru di sentra baru dan tiga hari bagi nasabah baru di sentra lama. PDK dilakukan agar nasabah menaati aturan-aturan pembiayaan yang diberikan BTPN Syariah.

MMS Depok jarang melakukan PDK karena MMS Depok lebih fokus pada masalah-masalah yang ada di sentra lama, yaitu penagihan kepada nasabah yang menunggak. Bahkan, pelaksanaan PDK oleh MMS Depok sering dilakukan pada saat pencairan pembiayaan dan pelaksanaan PDK hanya menjelaskan peraturan-peraturan pembiayaan saja, tidak mengenalkan profil BTPN Syariah. Sehingga, banyak nasabah yang tidak mengetahui kepada siapa mereka mengajukan pembiayaan.

Keempat, MMS Depok tidak paham isi akad sehingga tidak menyebutkan akad pada saat pencairan PMD. MMS Depok tidak memiliki sumber daya insani mengakibatkan MMS Depok minim pengetahuan tentang perbankan syariah. Sehingga, berdampak pada kesalahankesalahan dalam pelaksanaan akad PMD. Bahkan ketidakpahaman dialami oleh dua petinggi MMS Depok. Manager sentra (MS) MMS Depok 
beranggapan bahwa produk PMD sama dengan produk pembiayaan dari Bank Sahabat Purba Danarta yang menggunakan sistem kredit dan senior community officer (SCO) MMS Depok menyebutkan bahwa murabahah adalah pembiayaan menggunakan sistem bagi hasil.

Ketidakpahaman MMS Depok terhadap isi akad dan perjanjian, sehingga dalam pelaksanaan PMD MMS Depok tidak menyebutkan akad antara pihak bank dan nasabah yang mengarah kepada kesalahpamahan nasabah terhadap pembiayaan berbunga. Perjanjian dan akad sangat penting dilafalkan dan dipahami ketika melakukan transaksi muamalah, termasuk transaksi murabahah untuk menghindari kesalahpahaman terhadap pembiayaan berbunga. Beberapa pembina sentra (PS) MMS Depok mengikuti sistem yang dilakukan oleh petugas-petugas yang bertugas sebelumnya, pelaksanaan pembiayaan PMD tidak menyebutkan akad. PS hanya menyebutkan nominal dari pembiayaan, angsuran, dan tenor atau jangka waktu pembiayaan.

Karena ketidakpahaman akad PMD MMS Depok, nasabah melakukan penyelewengan terhadap dana pembiayaan. Beberapa nasabah menggunakan dana pembiayaan untuk keperluan pribadi atau keperluan sehari-hari (pembelian barang tidak sesuai dengan form AP3R). Bahkan beberapa nasabah menggunakan pembiayaan untuk keperluan konsumsi (form AP3R menjelaskan bahwa pembiayaan digunakan untuk pembiayaan usaha) dan menggunakan pembiayaan untuk menutupi hutang di lembaga keuangan lainnya.

Kemudian, MMS Depok tidak menindak lanjuti kesalahankesalahan yang dilakukan nasabah dalam penyimpangan dana, sehingga dapat merusak akad dan perjanjian. MMS Depok membiarkan kesalahan tersebut terjadi dan tidak memperbarui akad yang rusak. Bahkan MMS Depok tidak melakukan monitoring usaha (MU) untuk mengecek penggunaan dana yang benar dan penyelidikan terhadap kesehatan usaha nasabah.

Kelima, MMS Depok melaksanakan PMD dengan akad murabahah tidak disertai nota atau kwitansi pembelian barang, sehingga objek pembiayaan yang dilakukan adalah uang, bukan barang. Pelaksanaan pembiayaan PMD MMS Depok menyalahi perjanjian dimana akad yang digunakan adalah murabahah atau jual beli, dimana objek dari pembiayaan adalah barang, bukan uang. Pelaksanaan murabahah dilakukan setelah kepemilikan barang berpindah kepada bank, karena akad pertama adalah perwakilan atau wakalah. Setelah akad wakalah, maka selanjutnya akad murabahah. Nota atau kwitansi pembelian barang merupakan bukti pemindahan kepemilikan barang dari pembeli ke bank, sehingga selanjutnya bisa dilakukan akad murabahah.

Keenam, pelaksanaan akad wadiah dalam program PMD di MMS Depok hanya dapat dilakukan setiap pertemuan rutin sentra (PRS) atau dua 
minggu sekali. Penarikan dan tabungan tidak dapat dilakukan mendadak, harus melakukan pemesanan terlebih dahulu melalui penandatanganan slip penarikan tunai, kemudian akan diproses dua minggu yang akan datang pada PRS selanjutnya.

Ketentuan-ketentuan akad wadiah tidak dibacakan pada saat nasabah membuka rekening tabungan wadiah. Nasabah hanya diarahkan untuk melakukan pembukaan rekening ketika ingin mengajukan pembiayaan, karena tabungan merupakan salah satu fasilitas dari program PMD. Setelah nasabah memiliki tabungan, nasabah tidak dapat melakukan penarikan tunai secara mendadak, sehingga banyak nasabah yang complain kepada MMS Depok karena dianggap menahan uang nasabah yang seharusnya bisa diambil kapan saja.

Pelaksanaan murabahah pada program PMD BTPN Syariah di MMS Depok dapat digambarkan sebagai berikut:

Gambar 2. Skema pelaksanaan pembiayaan di MMS Depok

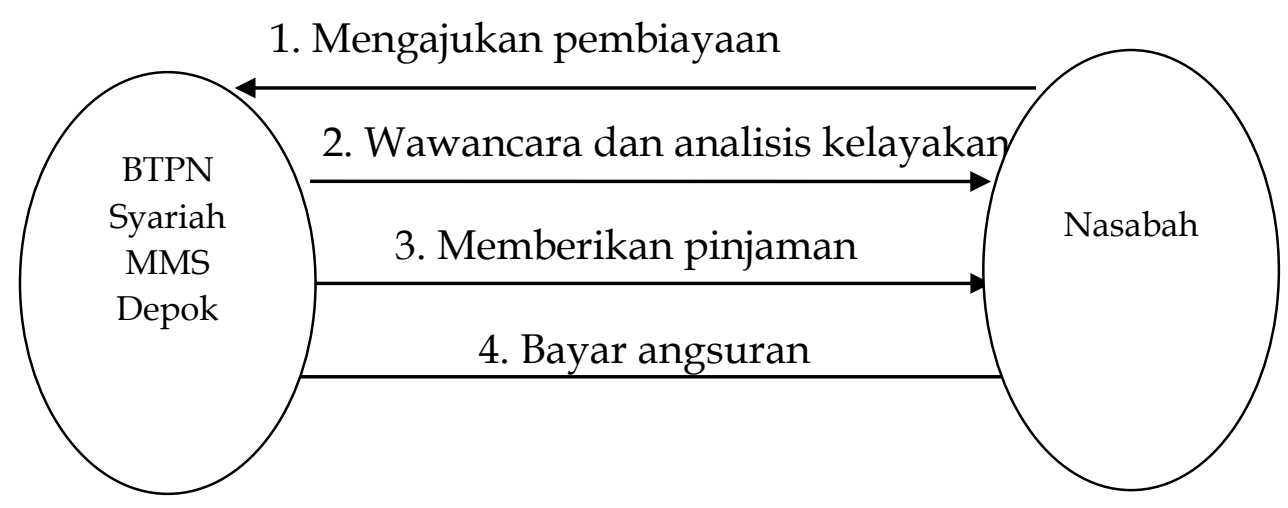

Nasabah mengajukan pembiayaan dan mengisi formulir permohonan AP3R kepada MMS Depok. MMS Depok mewawancarai dan menganalisa kelayakan usaha nasabah dan kelayakan nasabah untuk memperoleh fasilitas pembiayaan. MMS Depok memberikan pinjaman kepada nsabah. Pada saat pencairan pembiayaan, petugas MMS Depok membacakan kesepakatan pembiayaan, seperti jumlah dana yang cair, tenor waktu angsuran, dan jumlah angsuran yang dibayar setiap dua minggu. Nasabah membayar angsuran setiap dua minggu pada pertemuan rutin sentra (PRS).

\section{Pelaksanaan Program Paket Masa Depan (PMD) pada Mobile Marketing Syariah (MMS) Depok Perfektif Fiqh Muamalah}

Pihak MMS Depok dan nasabah tidak paham tentang produk PMD yang ditawarkan BTPN Syariah, termasuk tidak paham dalam penggunaan akad murabahah. Nasabah hanya mengetahui bahwa mereka meminjam uang atau modal usaha kepada BTPN Syariah dan mereka harus mencicil. Hal ini mengakibatkan pelaksanaan PMD tidak sesuai dengan ketentuan 
fiqh muamalah, dimana pelaksanaannya akan sama dengan pelaksanaan peminjaman kredit yang mengambil keuntungan dengan ribawi. Menurut Ali hasan, pelaksanaan akad tidak akan sah kecuali dengan shighat ijab qabul, untuk mengikat pihak-pihak terkait dalam perjanjian (Hasan, 2003:103). Dalam undang-undang No.21 tahun 2008 tentang bank syariah dinyatakan dalam pasal 1 angka 13, bahwa akad adalah kesepakatan tertulis antara bank syariah atau unit usaha syariah (UUS) dan pihak lain yang memuat adanya hak dan kewajiban bagi masing-masing pihak sesuai dengan prinsip syariah. Tanpa adanya akad, pihak nasabah maupun pihak MMS Depok akan merasakan bahwa pelaksaan PMD tidak memiliki perbedaan dengan peminjaman di bank konvensional yang mengandung bunga.

Akad menurut Ahmad Azhar Basyri adalah suatu perikatan antara ijab dan kabul dengan cara yang dibenarkan syara yang menetapkan akibat-akibat hukum. Ijab adalah pernyataan pihak pertama mengenai isi perikatan yang diinginkan dan kabul adalah pernyataan pihak kedua untuk menerimanya.

Hal lain yang terjadi ketika tidak paham tentang produk PMD adalah penyimpangan dana. Bentuk penggunaan atau pemakaian dana yang tidak sesuai dengan akad dan perjanjian disebut side streaming. Sehingga side streaming masuk dalam kategori penyimpangan. Dalam fiqh muamalah, hal tersebut termasuk membatalkan akad (fasakh) atau kelalaian dan kesalahan yang dilakukan dalam sebuah perjanjian atau akad, sehingga perjanjian atau akad tersebut harus dibatalkan. Pembatalan akad dengan mengakhiri transaksi sesuai kesepakatan sebelum terjadi karena ada kesalahan seperti dilakukannya side streaming dalam akad tersebut atau sebelum berakhirnya perjanjian atau akad. Pembatalan perjanjian atau akad tersebut, berbeda dengan berakhirnya akad. Dimana berakhirnya akad berarti telah selesai pelaksanaan perjanjian atau akad karena pihakpihak yang berkaitan telah memenuhi segala tanggung jawab yang mengikat, yang muncul dari perjanjian atau akad tersebut sehingga telah sampai pada tujuan yang dicapai oleh para pihak-pihak yang terkait dalam akad tersebut.

Secara hukum, pelaksanaan kasus side streaming pada penerapan wakalah dalam pembiayaan murabahah pada BTPN Syariah adalah terjadinya fasakh dalam perjanjian atau akad tersebut. Dengan demikian, perjanjian atau akad harus segera dibatalkan karena pihak nasabah telah menyalahi perjanjian.

Sesuai dengan ketentuan fatwa DSN-MUI nomor 04/DSNMUI/IV/ 2000 tentang akad murabahah bil wakalah, pelaksanaan pembiayaan yang dilakukan pihak BTPN Syariah dianggap sah dengan syarat barang yang menjadi objek pembiayaan, dibelikan nasabah untuk pihak BTPN Syariah (DSN MUIN, 2000:4). Kemudian barang tersebut 
dimiliki oleh pihak BTPN Syariah. Maka setelah itu, akad jual beli atau murabahah dapat dilaksanakan karena akad murabahah bil wakalah adalah akad jual beli, dimana bank atau lembaga keuangan syariah memberikan kuasa kepada nasabah untuk membeli sendiri barang yang dijadikan objek pembiayaan. Setelah barang tersebut dimiliki bank syariah dan harga barang tersebut jelas, maka pihak bank syariah menentukan keuntungan atau margin yang didapatkan serta menentukan jangka waktu pengembalian yang akan disepakati oleh pihak bank dan nasabah. Tapi, pelaksanaan akad wakalah dalam pembiayaan murabahah yang terjadi pada BTPN Syariah di MMS Depok berpotensi menimbulkan adanya side streaming.

Kasus side streaming pada pembiayaan PMD di BTPN Syariah MMS Depok dapat dikategorikan fasakh karena terdapat unsur kesalahan (ghalat) atau kekeliruan. Kekeliruan yang dimaksud terdapat pada objek akad atau kontrak. Nasabah BTPN Syariah MMS Depok yang melakukan kasus side streaming dapat dikategori sebagai fasakh karena kekeliruan dan kesalahan terletak pada objek akad murabahah (Resti dkk., 2018:384391).

Akan tetapi, BTPN Syariah tidak melakukan upaya untuk menyelesaikan kasus side streaming yang dilakukan nasabah. BPTN Syariah juga tidak melakukan upaya dalam rangka pencegahan terhadap kasus side streaming, sehingga kasus side streaming sangat sering dilakukan nasabah. Pembiayaan akan terus berjalan apabila ditemukan kasus side streaming.

Bahkan, Quality Assurance (QA) area jogja-jawa tengah menyebutkan bahwa tidak adanya nota atau kwitansi pembelian barang bukan kasus kesalahan yang bersifat high risk. Dengan tidak adanya nota atau kwitansi pembelian barang berarti mengabaikan kepemilikan barang tersebut oleh pihak bank. Sehingga, objek jual beli yang dilakukan bukan barang, tapi uang. Pelaksanaan murabahah BTPN Syariah MMS Depok dalam produk PMD mengabaikan status kepemilikan barang atau objek yang diakadkan. Pada praktek akad murabahah dalam produk PMD melaksanakan akad tanpa adanya kepemilikan barang. Dalam fatwa DSN-MUI No.4/DSNMUI/IV/2000 tentang murabahah, ditegaskan dalam poin ke-9 bahwa "jika bank hendak mewakilkan kepada nasabah untuk membeli barang dari pihak ketiga, akad jual beli murabahah harus dilakukan setelah barang, secara prinsip menjadi milik bank."

Nasabah diberikan pembiayaan dengan mengabaikan objek dalam jual beli. Sehingga menimbulkan stigma bagi nasabah yang terbiasa dengan skim kredit konsumtif bahwa bank Syariah sama dengan bank konvensional, karena kebutuhan nasabah bukan untuk pembelian barang, tapi kebutuhan nasabah adalah dana segar. Setelah dana dicairkan, nasabah tidak mempunyai kewajiban untuk menyerahkan kwitansi atau nota 
sebagai barang tersebut telah dibeli, sehingga kepastian akad murabahah dan juga akad wakalah yang melekat pada pembiayaan murabahah tidak terlaksana dengan baik. Praktek murabahah ini menunjukkan adanya penyimpangan dari aturan fiqh muamalah. Penyimpangan berupa selipan akad wakalah dalam transaksi murabahah. Praktek murabahah seperti ini menyerupai transaksi kredit pada perbankan konvensional (Afrida, 2016:155-166).

Kemudian, plafond pembiayaan telah ditentukan sebelumnya, dimana keuntungan atau margin dihitung berdasarkan plafond yang ditawarkan kepada nasabah. Sedangkan dalam fiqh muamalah, perhitungan keuntungan atau margin murabahah harus berdasarkan harga barang. Objek pelaksanaan murabahah adalah barang, sehingga perhitungan margin harus dilakukan setelah barang diketahui harganya, bukan yang telah ditentukan sebelumnya. Dalam fatwa DSN-MUI No.04/DSN-MUI/IV/2000 tentang murabahah mendefinisikan murabahah sebagai kegiatan menjual suatu barang dengan menyebutkan harga belinya kepada pembeli dan pembeli membayarnya dengan harga tersebut ditambah margin atau laba. Bank harus menyediakan barang yang diinginkan nasabah dalam akad pembiayaan murabahah. Apabila pembiayaan murabahah diawali dengan akad wakalah yang diwakilkan oleh nasabah, maka nasabah harus menyerahkan bukti pembelian bang berupa kwitansi atau nota kepada pihak bank sebagai bukti perpindahan kepimilikan barang (OJK, 2016:20).

MMS Depok yang tidak menyebutkan akad, tidak memberitahu secara jelas akad apa yang digunakan dalam tabungan sehingga menimbulkan persfektif lain. Pelaksanaan wadiah MMS Depok tidak sesuai dengan fatwa DSN No.02/DSN-MUI/IV/2000 tentang tabungan yang menjelaskan tentang tabungan wadiah dapat diambil kapan saja (on call) atau berdasarkan kesepakatan. MMS Depok tidak menjelaskan sistem tabungan kepada nasabah. Setelah perjanjian ditanda tangani, MMS Depok melaksanakan sistem tabungan dimana tabungan wadiah tidak bisa diambil kapan saja, tetapi melalui pemesanan dan hanya boleh dilakukan ketika PRS (Pertemuan Rutin Sentra).

\section{KESIMPULAN}

MMS Depok dan nasabah tidak paham tentang akad paket masa depan (PMD) yang ditawarkan BTPN Syariah, mengakibatkan pelaksanaan yang produk Paket Masa Depan tidak sesuai dengan ketentuan fiqh muamalah, dimana pelaksanaannya akan sama dengan pelaksanaan peminjaman kredit yang mengambil keuntungan dengan ribawi. Kemudian, nasabah melakukan penyimpangan penggunaan dana. Pelaksanaan kasus side streaming pada penerapan wakalah dalam pembiayaan murabahah pada BTPN Syariah merupakan fasakh dalam 
perjanjian/akad tersebut, karena terdapat unsur kesalahan (ghalat) atau kekeliruan, dimana kekeliruan yang dimaksud terletak pada objek perjanjian atau akad. Objek akad dalam pembiayaan merupakan bentuk uang, bukan barang. Seharusnya, objek dalam akad adalah barang. Plafond pembiayaan telah ditentukan sebelumnya, dimana keuntungan atau margin dihitung berdasarkan plafond yang ditawarkan kepada nasabah. Sedangkan dalam fiqh muamalah, perhitungan keuntungan atau margin murabahah harus berdasarkan harga barang. Pelaksanaan wadiah tidak bisa diambil kapan saja, tetapi melalui pemesanan dan hanya boleh dilakukan ketika pertemuan rutin sentra.

\section{DAFTAR PUSTAKA}

Afrida, Yenti., Analisis Pembiayaan Murabahah di Perbankan Syariah, JEBI (Jurnal Ekonomi dan Bisnis Islam), Vol. 1, No. 2, Juli-Desember 2016. Ali, Syukriah, dkk, The Determining Factors of Wadiah Saving Deposits in Malaysia, Elixir International Journal, Vol. 43, 2012.

Arifin, Djohar, 2014, Substansi Akad Dalam Transaksi Syariah, Al-Amwal, Vol 6, No.1, 2014.

Ascarya, Akad dan Produk bank Syariah Konsep dan Praktek di Beberapa Negara, Jakarta: Rajawali Pers, 2013.

Azhar Basyri, Ahmad, Azas-azas Hukum Muamalah, Yogyakarta:UII Press, 2004

Azharuddin Lathif, Ah, Konsep dan aplikasi akad murabahah pada perbankan syariah di Indonesia, Ahkam: jurnal Ilmu Syariah, Vol. 12, No. 2, Juli 2012.

Bank BTPN Syariah, "Paket Masa Depan", dikutip dari https://www.btpnsyariah.com/index.php/id/produk/pembiayaa n/paket-masa-depan.html.

BTPN Syariah, Panduan Paket Masa depan, Edisi Revisi tahun 2012, Jakarta: BTPN Syariah, 2012.

Departemen Agama RI, Mushaf Al-Qur'an dan Terjemah, Jakarta: Pustaka AlKautsar, 2009.

Desminar, Akad Wadiah Dalam Perspektif Fiqih Muamalah, Menara Ilmu, Vol. XIII, No. 3, Januari 2019.

Devisi Pengembangan Produk dan Edukasi, Standar Produk Bank Syariah Murabahah, Jakarta: Departemen Perbankan Syariah dan Otoritas Jasa Keuangan, 2016.

Dewan Syariah Nasional Majelis Ulama Indonesia, Himpunan Fatwa Dewan Syariah Nasional, Jakarta: CV. Gaung Persada Press, 2016

Hadi, A. Chairul, Problematika Pembiayaan Mudharabah, Al-Iqtishad, Vol III, No. 2, 2011. 
Hakim, Lukmanul., Anwar, Amelia., Pembiayaan Murabahah Pada Perbankan Syariah Dalam Perspektif Hukum di Indonesia, Al-Urban: Jurnal Ekonomi Syariah dan Filantropi Islam, Vol. 1, No. 2, Desember 2017.

Hasan, M. Ali, Berbagai Macam Transaksi dalam Islam (figh Muamalat), Jakarta: PT Raja Grafindo Perasada, 2003.

Hasbi, Muhammad, Pengantar Fiqih Muamalat, Semarang: Pustaka Rizki Putra, 1997.

Hidayat, Enang, Transaksi Ekonomi Syariah, Bandung: Remaja Rosdakarya, 2015.

Huda, Nurul., Heykal, Muhamad., Lembaga Keuangan Islam Tinjauan Teoretis Dan Praktis, Jakarta: Kencana Prenada Media Group, 2013.

Huda, Qamarul, Fiqh Muamalah, Yogyakarta: Teras, 2011.

Ibrahim, Ahmad Basri bin, Noor, Azman bin Mohd, The Application of Wadi'ah Contract By Some Financial Institutions in Malaysia, International Journal of Business and Social Science, Vol. 2, No.3, 2011.

Idris, Fiqh Menurut Madzhab Syafi'i, Jakarta: Widjaya, cet 1, 1969.

Maulidiana, Lina, Penerapan Prinsip-prinsip Murabahah dalam Perjanjian Islam (Kajian Operasional Bank Syariah dalam Modernisasi Hukum), Jurnal Sains dan Inovasi, Vol.7, No. 1, 2011.

Moleong, Lexy J., Metodologi Penelitian Kualitatif, Bandung: PT. Remaja Rosdakarya.

Mustapha, Muhammed, The Case for Integration of Islamic Banking Principles Into The Nigerian Banking System, African Journal of Social Science, Vol. 2, No. 2, 2012.

Pemerintah Indonesia, Undang-undang No.10 Tahun 1998, Jakarta: Sekretariat Negara, 1998.

Pemerintah Indonesia, Undang-undang Nomor 21 Tahun 2008, Jakarta: Sekretariat Negara, 2008.

Rejeki, Fanny Yunita Sri, Akad Pembiayaan Murabahah dan Praktiknya Pada PT Bank Syariah Mandiri Cabang Manado, Lex Privatum, Vol. 1, No. 2.

Risanawati, Resti., dkk, Tinjauan fikih muamalah terhadap side streaming dalam Pelaksanaan akad wakalah pada pembiayaan murabahah di BJB Syariah kantor pusat Braga Kota Bandung, Prosiding Hukum Ekonomi Syariah, Vol. 4, No. 1, Februari 2018.

Sabir, Muh, dkk, Pengaruh Rasio Kesehatan Bank Terhadap Kinerja Keuangan Bank Umum Syariah dan Bank Konvensional di Indonesia, Jurnal Analisis, Vol. 1, No.1, 2012.

Sudarsono, Heri., Bank dan Lembaga Keuangan Syariah, Yogyakarta: Ekonisia, 2004.

Suhendi, Hendi, Figh Muamalah, Jakarta: Raja Grafindo, Persada, 2008.

Syafei, Rachmad., Fiqh Muamalah, Bandung: Pustaka Setia, 2001. 
Syafi'i Antonio, Muhammad., Bank Syariah Dari Teori Ke Praktik, Jakarta: Gema Insani, 2001.

Wangsawidjaya Z, Pembiayaan Bank Syariah, Jakarta: Gramedia Pustaka Utama, 2012.

Warson Munawwir, Ahmad., Al-Munawwir, Kamus Arab-Indonesia, Cet. IV, Surabaya: Pustaka Progressif, 1997.

Zuriah, Nurul, Metodologi Penelitian Sosial dan Pendidikan Teori-Aplikasi, Jakarta: PT. Bumi Aksara. 